\title{
Morphological Changes and Reorganization of Actinfilaments in Human Myeloid Leukemia Cells Induced by a Novel Protein Phosphatase Inhibitor, Tautomycin
}

\author{
Tomohiro Kurisaki ${ }^{1}$, Junji Magae ${ }^{*, 2}$, Kazuo Nagai ${ }^{2}$, Aiko Hirata ${ }^{3}$, Iwao Kusaka ${ }^{3}$, Hitomi Shinji ${ }^{4}$, \\ Minoru Morikawa ${ }^{4}$, Takeshi Yoshida ${ }^{4}$, Kiyoshi Isono ${ }^{5}$, and Makari Yamasaki ${ }^{1}$ \\ ${ }^{1}$ Department of Agricultural Chemistry, The University of Tokyo, 1-1-1 Yayoi, Bunkyo-ku, Tokyo 113, \\ ${ }^{2}$ Department of Bioengineering, Tokyo Institute of Technology, 4259 Nagatsuta-cho, Midori-ku, Yokohama \\ 227, 'Institute of Applied Microbiology, The University of Tokyo, 1-1-1 Yayoi, Bunkyo-ku, Tokyo 113, \\ ${ }^{4}$ Tokyo Institute of Immunopharmacology, Inc., 3-41-8 Takada, Toshima-ku, Tokyo 171, and ${ }^{5}$ IKEN, The \\ Institute of Physical and Chemical Research, Wako-shi, Saitama 351-01, Japan
}

Key word: tautomycin/protein phosphatase/actinfilament/cytoskeleton

\begin{abstract}
$A B S T R A C T$. A protein phosphatase inhibitor, tautomycin induces blebs on the surface of human myeloid leukemia $\mathrm{K} 562$ cells within $10 \mathrm{~min}$. In this paper we examined the cytoskeleton of tautomycin-treated cells. In the presence of tautomycin, cells with blebs turned into segmented forms with smooth surfaces after 15 min and into smooth round shapes without microprotuberance after $60 \mathrm{~min}$. Observation with fluorescence microscopy showed that F-actin detached from the plasma membrane at the site of the blebs. Further treatment with tautomycin induced the accumulation of $F$-actin at the segmentation centers. Under electron microscopy, an electron dense ring-structure was detected at the segmentation center. Tautomycin did not induce major changes of the microtubule network although $\mathrm{F}$-actin accumulated near the microtubule organizing center. The amount of $\mathrm{F}$-actin increased in tautomycin-treated cells. These results indicate that the morphological changes are induced by reorganization of actinfilaments.
\end{abstract}

Reversible phosphorylation of protein is recognized as one of the most important mechanisms of regulating intracellular events in eukaryotic cells. Protein phosphorylation activates or inactivates various kinases, and the balanced reactions between protein kinases and protein phosphatases regulate various cellular events (1).

Tautomycin is an antifungal antibiotic isolated from Streptomyces spiroverticillatus (2-4). This drug induced blebs on the surface of human myeloid leukemia K562 $(5,6)$. Similar morphological changes are also induced by phorbol dibutyrate (PDBu) and cytochalasin $\mathrm{D}(6)$. Recently, we found that non-phorbol-12-tetradecanoate-13-acetate (TPA)-type tumor promoters, okadaic acid and calyculin $A(7,8)$, have a similar effect on the morphology and protein phosphorylation of K562 cells

\footnotetext{
* To whom all correspondence should be addressed.

Abbreviations: DAPI, 4,6-diamidino-2-phenylindole; DNaseI, deoxyribonuclease I; $\mathrm{ED}_{50}, 50 \%$ effective dose; FCS, fetal calf serum; $\mathrm{IC}_{50}, 50 \%$ inhibitory concentration; MLC, myosin light chain; MTOC, microtubule organizing center; PBS, phosphate buffered saline; $\mathrm{PDBu}$, phorbol dibutyrate; $\mathrm{PKC}$, protein kinase $\mathrm{C}$; PP1, type I protein phosphatase; PP2A, type IIA protein phosphatase; SEM, scanning electron microscopy; TEM, transmission electron microscopy; TPA, phorbol-12-tetradecanoate-13-acetate
}

as tautomycin, and that tautomycin as well as okadaic acid inhibits protein phosphatases $(9,10)$. Further studies on this drug revealed that it is a novel inhibitor of protein phosphatases (9) with a specificity for enzyme subspecies that is distinct from those of okadaic acid and calyculin $\mathrm{A}(11,12)$.

Cell morphology is determined by the cytoskeleton, which is composed of three types of filaments, actinfilaments, microtubules and intermediate filaments. Since cytochalasin D induced morphological changes in K562 cells similar to those of tautomycin (6), it is possible that tautomycin modulates actinfilaments through the inhibition of protein phosphatases. In this paper, we examined the effect of tautomycin on the cytoskeleton of $\mathrm{K} 562$ cells and found that the antibiotic induced characteristic reorganization of actinfilaments in cells.

\section{MATERIALS AND METHODS}

Chemicals. Tautomycin was isolated from culture broth of Streptomyces spiroverticillatus as described previously (2). Staurosporine was isolated from the culture broth of an unidentified strain of actinomycetes. Okadaic acid was kindly donated by Dr. H Fujiki (National Cancer Research Institute, 
Japan). Cytochalasin D and PDBu were purchased from Sigma Chem.. Calyculin A was a kind gift from Dr. N. Fusetani (University of Tokyo).

Cell culture. Cells were cultured in RPMI1640 medium supplemented with $10 \%$ fetal calf serum (FCS), $0.05 \mathrm{mM} \mathrm{2-}$ mercaptoethanol, $0.05 \mathrm{mg} / \mathrm{ml}$ kanamycin, $0.008 \mathrm{mg} / \mathrm{ml}$ tylosin tartrate at $37^{\circ} \mathrm{C}$ in $5 \% \mathrm{CO}_{2}$ atmosphere.

Electron microscopy. For scanning electron microscopy (SEM), cells were fixed and pelleted with $2.5 \%$ glutalaldehyde in $0.05 \mathrm{M}$ phosphate buffer ( $\mathrm{pH} 6.95$ ), postfixed in $1 \% \mathrm{OsO}_{4}$, dehydrated in ethanol and critical-point dried in $\mathrm{CO}_{2}$. Goldcoated specimens were examined in a SEM (Hitachi S-2400). For transmission electron microscopy (TEM), cells were fixed and pelleted with $2 \%$ glutalaldehyde and $2 \%$ paraformalde-

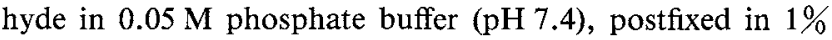
$\mathrm{OSO}_{4}$, dehydrated in ethanol, infiltrated and embedded in Spurr's resin. They were then polymerized in capsules at $50^{\circ} \mathrm{C}$ for $5 \mathrm{hr}$ and $70^{\circ} \mathrm{C}$ for $30 \mathrm{hr}$. Thin sections cut with Sorvall MT-2 ultramicrotome were collected, stained with uranyl acetate for $2 \mathrm{hr}$ and lead citrate for $10 \mathrm{~min}$ and observed under TEM (JOEL 200CX, Japan) at $100 \mathrm{kV}$.

Fluorescent labeling. Rhodamine-phalloidin (Wako Pure Chem., Japan) was used for the detection of F-actin, and 4,6diamidino-2-phenylindole (DAPI) for visualizing nuclei. Cellular tubulin was stained by an indirect immunofluorescence method. Cells were attached to a slide glass with cytospin (500 rpm, $2 \mathrm{~min}$ ). The preparation was fixed with $3.5 \%$ formaldehyde in phosphate buffered saline (PBS, $0.8 \% \mathrm{NaCl}, \mathrm{pH}$ 7.4), washed with PBS, treated with $0.2 \%$ Triton X-100, washed with PBS and treated with blocking buffer (10\% FCS,
$3 \%$ bovine serum albumin, $0.05 \%$ Tween- $20,0.02 \% \mathrm{NaN}_{3}$ in PBS) for $30 \mathrm{~min}$ at $37^{\circ} \mathrm{C}$. After washing 3 times with washing buffer (PBS containing 0.05\% Tween-20), cells were incubated with the first antibody (mouse anti- $\alpha$-tubulin, Amersham) for $30 \mathrm{~min}$ at $37^{\circ} \mathrm{C}$, washed with washing buffer and incubated with the second antibody (anti-mouse IgG labeled with FITC, E.Y. Laboratories) for $30 \mathrm{~min}$ at $37^{\circ} \mathrm{C}$. Staining with DAPI $(50 \mathrm{ng} / \mathrm{ml})$ or with rhodamine-phalloidin $(6 \mathrm{unit} / \mathrm{ml})$ was carried out after fixation.

Determination of the actin content in cells. After cells were washed with HBSS, monomer actin was extracted by treatment for $5 \mathrm{~min}$ at $0^{\circ} \mathrm{C}$ with an extraction solution containing $0.1 \%$ Triton X-100, $100 \mathrm{mM} \mathrm{NaCl}, 2 \mathrm{mM} \mathrm{MgCl}_{2}, 0.001$ $\mathrm{mg} / \mathrm{ml}$ pepstatin A, $0.01 \mathrm{mM}$ ATP, $0.01 \mathrm{mg} / \mathrm{ml}$ trypsin inhibitor, $0.5 \mathrm{mM}$ PMSF, $0.2 \mathrm{mM}$ dithiothreitol and $10 \mathrm{mM}$ HEPES ( $\mathrm{pH} 7.5$ ). Lysate were centrifuged at $15,000 \mathrm{~g}$ for 5 min in order to remove debris. The amount of actin in extracts was measured with a modified deoxyribonuclease I (DNase I) inhibition assay as described previously using rabbit skeletal muscle actin (Sigma Chem.) as standard (13). In order to determine the total actin content, cells were homogenized and sonicated in actin extraction solution and the actin content was measured.

\section{RESULTS}

The surface of the cells treated with drugs was examined by SEM (Fig. 1). Blebs were observed on K562 cells within $5 \mathrm{~min}$ after the addition of tautomycin. Thereafter, the cells were segmented and, at $60 \mathrm{~min}$ after the
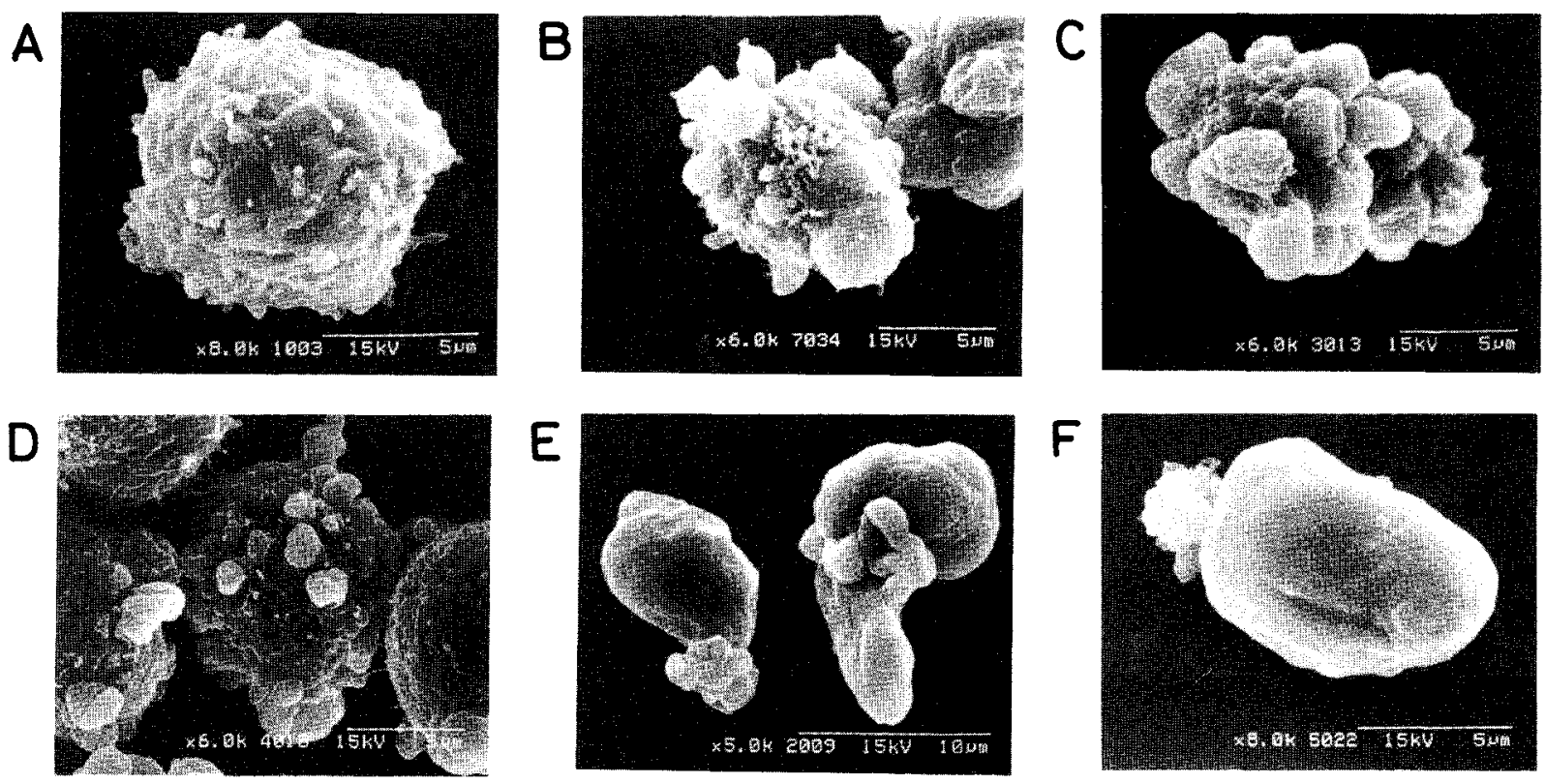

Fig. 1. SEM observation of K562 cells treated with tautomycin and PDBu.

A, untreated cells. Cells were treated with PDBu $(1 \mu \mathrm{g} / \mathrm{ml}$; B, C) or tautomycin (30 $\mu \mathrm{g} / \mathrm{ml} ; \mathrm{D}, \mathrm{E}, \mathrm{F})$ for $5 \mathrm{~min}(\mathrm{~B}, \mathrm{D}), 15 \mathrm{~min}(\mathrm{C}, \mathrm{E})$, or $30 \mathrm{~min}$ (F). 
addition of tautomycin, they looked like smooth round shapes without microprotuberances. It should be noted that small remnants of blebs could always be seen on the surface of the smooth round cells. PDBu, an activator of protein kinase C (PKC) (14), also induced blebs on the surface of K562 cells within $10 \mathrm{~min}$, but did not induce the changes into segmented forms or the smooth round shapes.

Cytochalasin D also induced blebs in K562 cells (6), indicating that actinfilaments were involved in the morphological changes. The distribution of F-actin was examined by fluorescence microscopy using a rhodaminephalloidin probe (Fig. 2). No characteristic structure was seen in untreated cells whereas an accumulation of F-actin was observed at the segmentation center in the cells treated with tautomycin for $20 \mathrm{~min}$. A similar accumulation was also present in the cells treated with okadaic acid or calyculin A, known inhibitors of protein phosphatases (15-17). In PDBu-treated cells, however, no accumulation of F-actin was observed. Giant clusters of F-actin were observed in cytochalasin Dtreated cells although they were large and disperse compared with the accumulation center induced by tautomycin.

Figure 3 shows changes in F-actin and nuclei of tautomycin-treated K562 cells as a function of time. Blebs be-

\section{A}

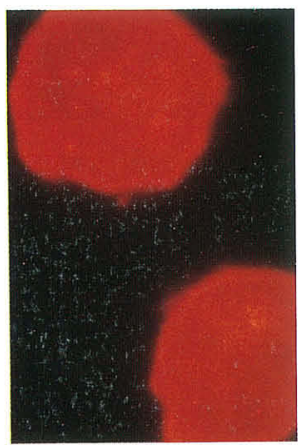

E

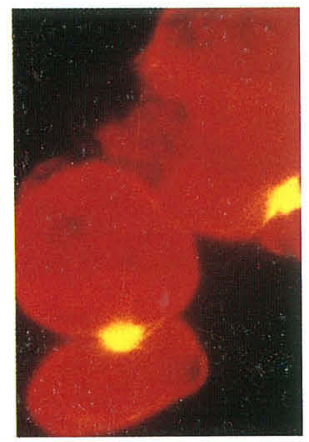

1

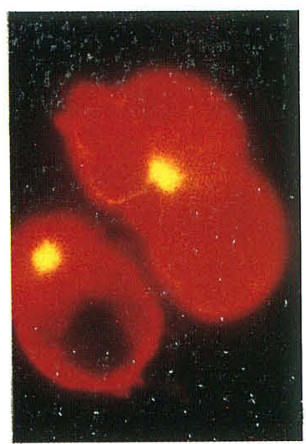

B

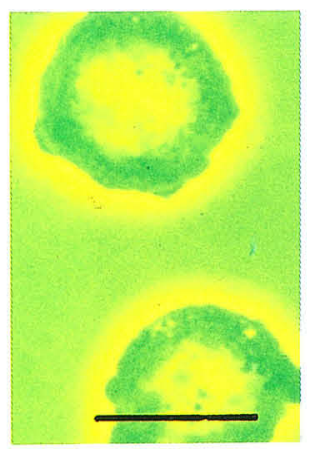

$F$

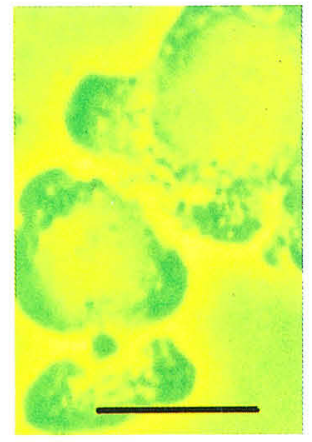

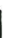

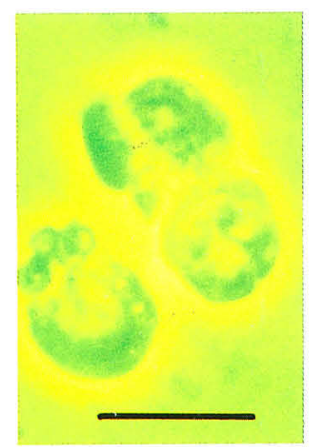

C

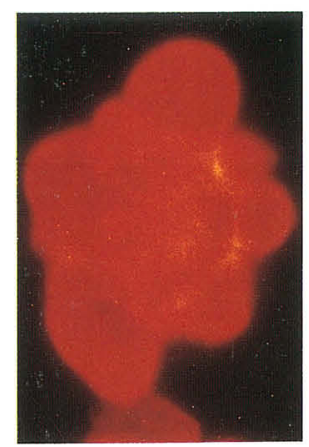

G

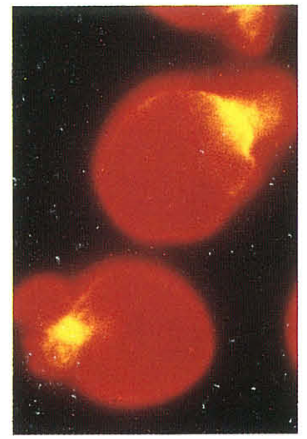

K

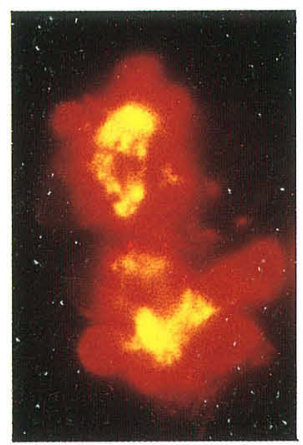

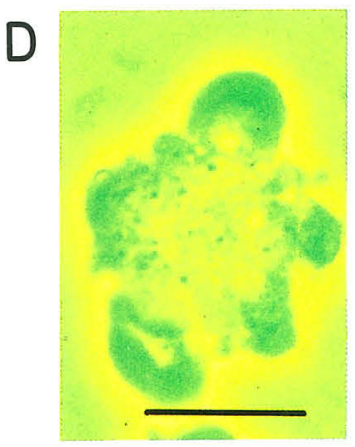

$\mathrm{H}$

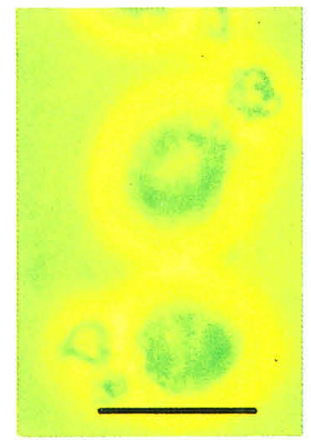

L

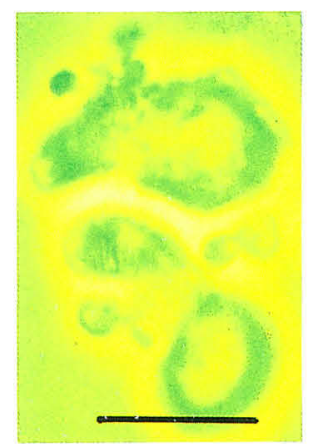

Fig. 2. Changes in F-actin in K562 cells.

Untreated cells; A, B. Cells were treated with PDBu $(1 \mu \mathrm{g} / \mathrm{ml}$; C, D), tautomycin (30 $\mu \mathrm{g} / \mathrm{ml}$; E, F), okadaic acid (10 $\mu \mathrm{g} / \mathrm{ml}$; G, H), calyculin A $(0.3 \mu \mathrm{g} / \mathrm{ml} ; \mathrm{I}, \mathrm{J})$, or cytochalasin D $(0.3 \mu \mathrm{g} / \mathrm{ml} ; \mathrm{K}, \mathrm{L})$ for $20 \mathrm{~min}$. F-actin of cells was labeled with rhodamine-phalloidin and observed with fluorescence microscopy. A, E, I, C, G, K; fluorescence microscopy. B, F, J, D, H, L; phase contrast of the same field. Bars; $10 \mu \mathrm{m}$. 
gan to appear within several minutes after the addition of tautomycin. At this time, the accumulation of F-actin was not yet observed. Instead, a thin layer of F-actin was observed just below the surface of cells except those of blebs. Thereafter, one accumulation center was formed per cell at the center of segmentation at $20 \mathrm{~min}$ after the addition of tautomycin. Once the actin accumulation appeared, it did not disappear even after the cells turned into round shapes. Actin accumulation could always be seen just below the small remnants of blebs.

As the morphological changes progressed, the morphology of nuclei also changed and finally returned to the original morphology when the segmented cells changed into the smooth round shapes. This suggested that tautomycin had only minimal effect on the structure of nuclei. Tautomycin did not affect the microtubule network although the microtubule organizing cen-
A

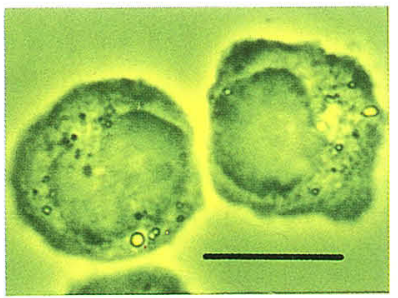

D

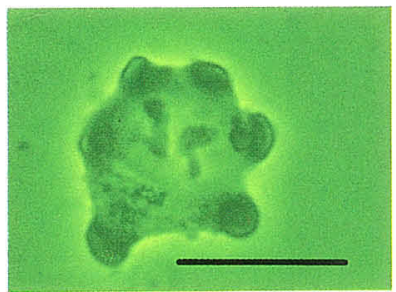

G

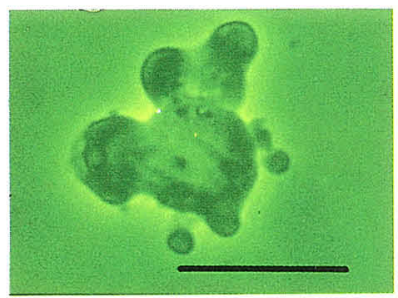

J

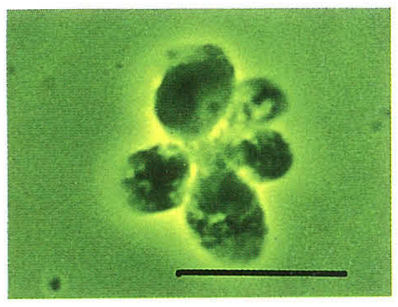

M

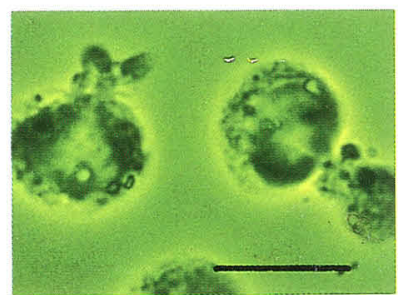

B

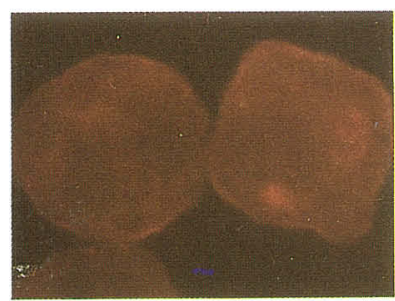

E

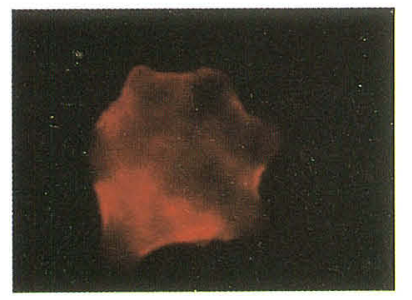

H

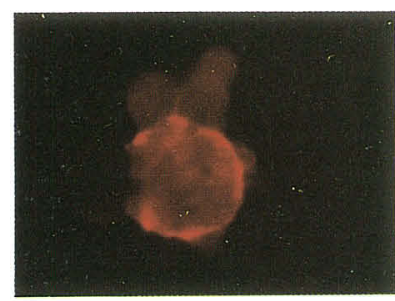

K

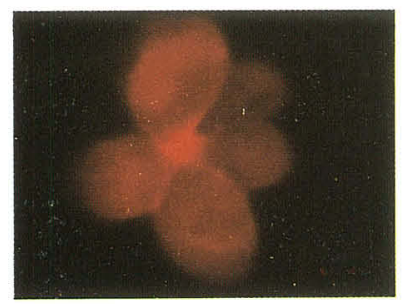

N

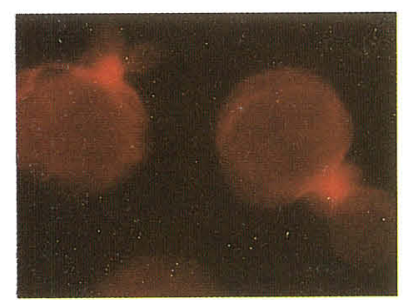

C

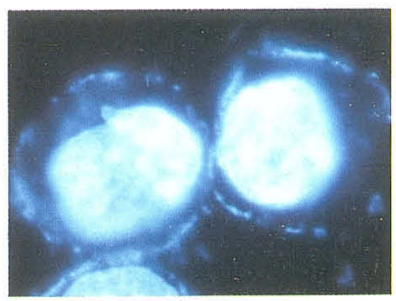

F

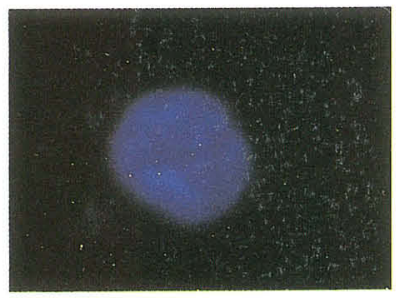

I

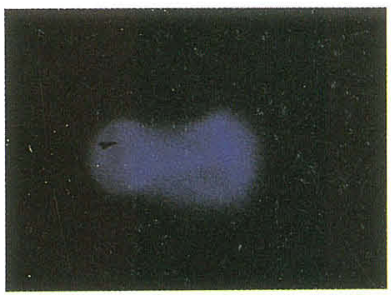

L

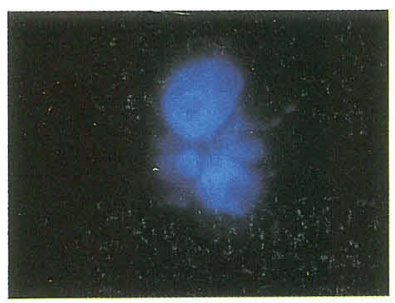

0

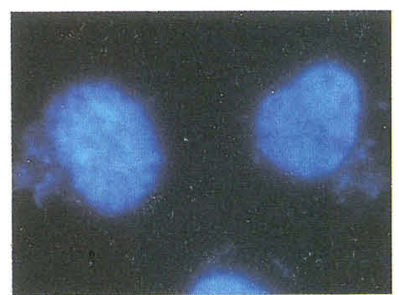

Fig. 3. Changes in F-actin and nuclei as a function of time of treatment with tautomycin.

K562 cells were treated with tautomycin $(30 \mu \mathrm{g} / \mathrm{ml})$ for $3 \mathrm{~min}(\mathrm{D}, \mathrm{E}, \mathrm{F}), 5 \mathrm{~min}(\mathrm{G}, \mathrm{H}, \mathrm{I}), 20 \mathrm{~min}(\mathrm{~J}, \mathrm{~K}, \mathrm{~L}), \mathrm{or} 45 \mathrm{~min}(\mathrm{M}, \mathrm{N}, \mathrm{O})$. Untreated cells; A, B, C. Cells were fixed and stained with rhodamine-phalloidin (B, E, H, K, N) and DAPI (C, F, I, L, O). A, D, G, J, M; phase contrast observation of the same field. Bars; $10 \mu \mathrm{m}$. 

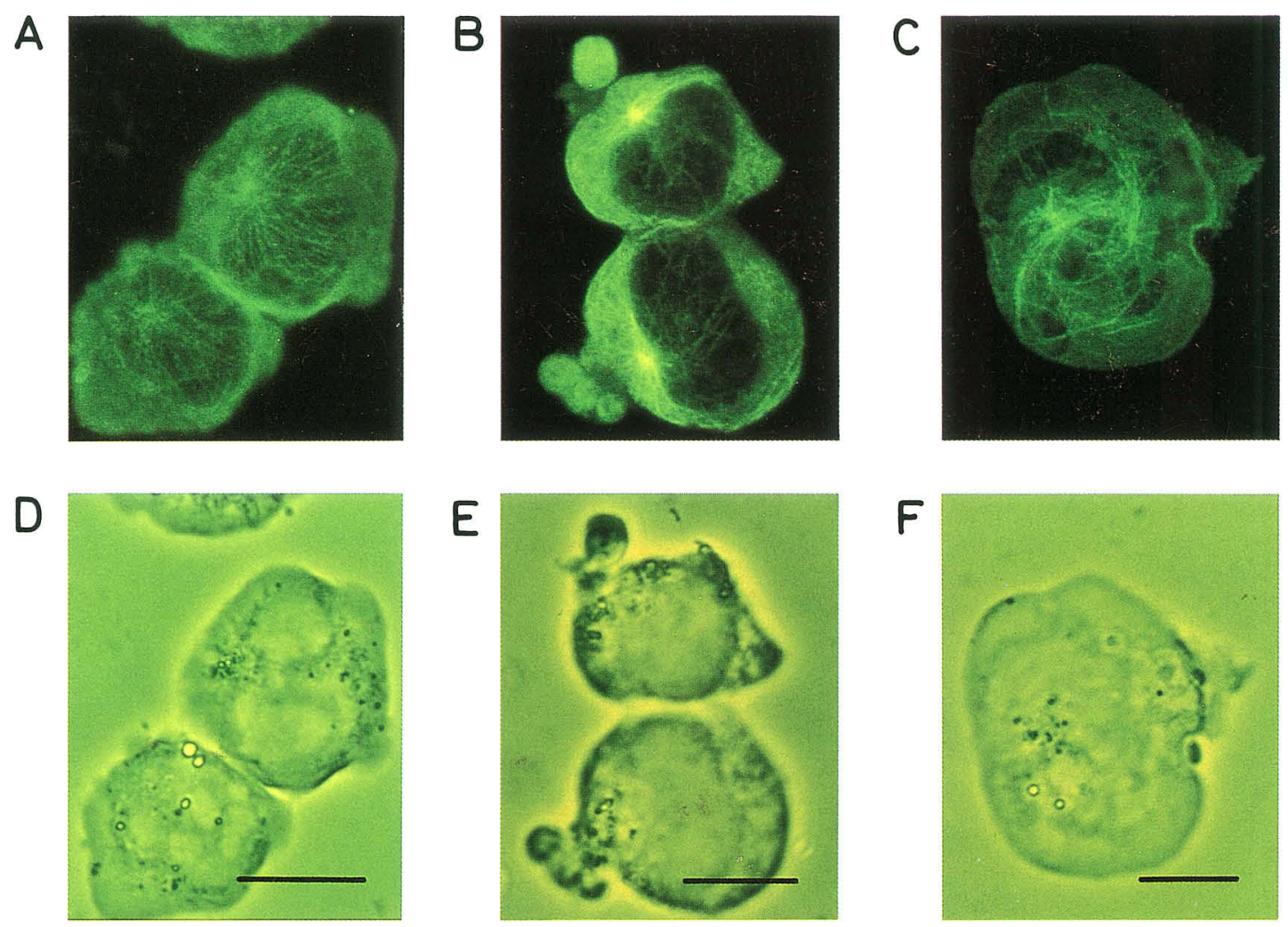

Fig. 4. Effect of tautomycin on the microtubule network.

A, D; untreated cells. K562 cells were treated with tautomycin $(30 \mu \mathrm{g} / \mathrm{ml})$ for $15 \mathrm{~min}$ (B, E) or $45 \mathrm{~min}(\mathrm{C}$, F). Cells were fixed and the tubulin network was stained by indirect immunofluorescence (A, B, C). D, E, F; phase contrast observation of the same field. Bars; $10 \mu \mathrm{m}$.

ter (MTOC) could always be seen in the perinuclear region near the segmentation center (Fig. 4). Pretreatment of cells with colchicine $(1 \mu \mathrm{g} / \mathrm{ml})$ for $1 \mathrm{hr}$ did not prevent the morphological changes and the accumulation of F-actin (data not shown).

We also examined the amount of monomer actin in cells by the DNase I inhibition assay (Table I). Almost all of the actin was monomer in the untreated cells, whereas monomeric actin in tautomycin-treated cells decreased to $55 \%$ of the total actin. F-actin content in untreated cells was low compared with previous report (18). It is possible that sonication incompletely mono-

Table I. EFFECT OF TAUTOMYCIN ON THE ACTIN REORGANIZATION OF K562 CELLS.

\begin{tabular}{cccc}
\hline \multirow{2}{*}{ tautomycin } & \multicolumn{3}{c}{ actin content $\left(\mu \mathrm{g} / 10^{6}\right.$ cells $)$} \\
\cline { 2 - 4 } & monomer & total & ratio $(\%)^{\mathrm{a}}$ \\
\hline- & $52.3 \pm 12.5$ & $56.34 \pm 12.5$ & 93 \\
+ & $32.3 \pm 4.0$ & $58.34 \pm 5.89$ & 55
\end{tabular}

K562 cells were treated with tautomycin $(10 \mu \mathrm{g} / \mathrm{ml})$ for $30 \mathrm{~min}$ in triplicate. Cells were washed and actin extracted was measured as described in Materials and Methods. Another experiment showed a similar result.

a percent of monomer actin to total actin. merized F-actin.

The structure of the segmented cells was examined by TEM (Fig. 5). Complex foldings of plasma membrane and a ring-shaped electron-dense structure, which we assumed to be the accumulation of F-actin, were observed at the segmentation center. Such structures were never observed in untreated cells or cells treated with PDBu.

\section{DISCUSSION}

Morphological changes induced by tautomycin consist of two stages (6). In the first stage, the blebs are formed on the surface of cells. In the second stage, cells are segmented and finally become smooth round shapes. The present results suggest that this process proceeds through the reorganization of actinfilaments including accumulation and polymerization of F-actin.

Okadaic acid and calyculin A, inhibitors of protein phosphatases, induced similar morphological changes and reorganization of actinfilaments, indicating that the changes involve phosphorylation due to inhibition of phosphatases. Type I phosphatase (PP1) might be related to the changes because it is associated with actomyosin and regulates its activity (1). In addition, 

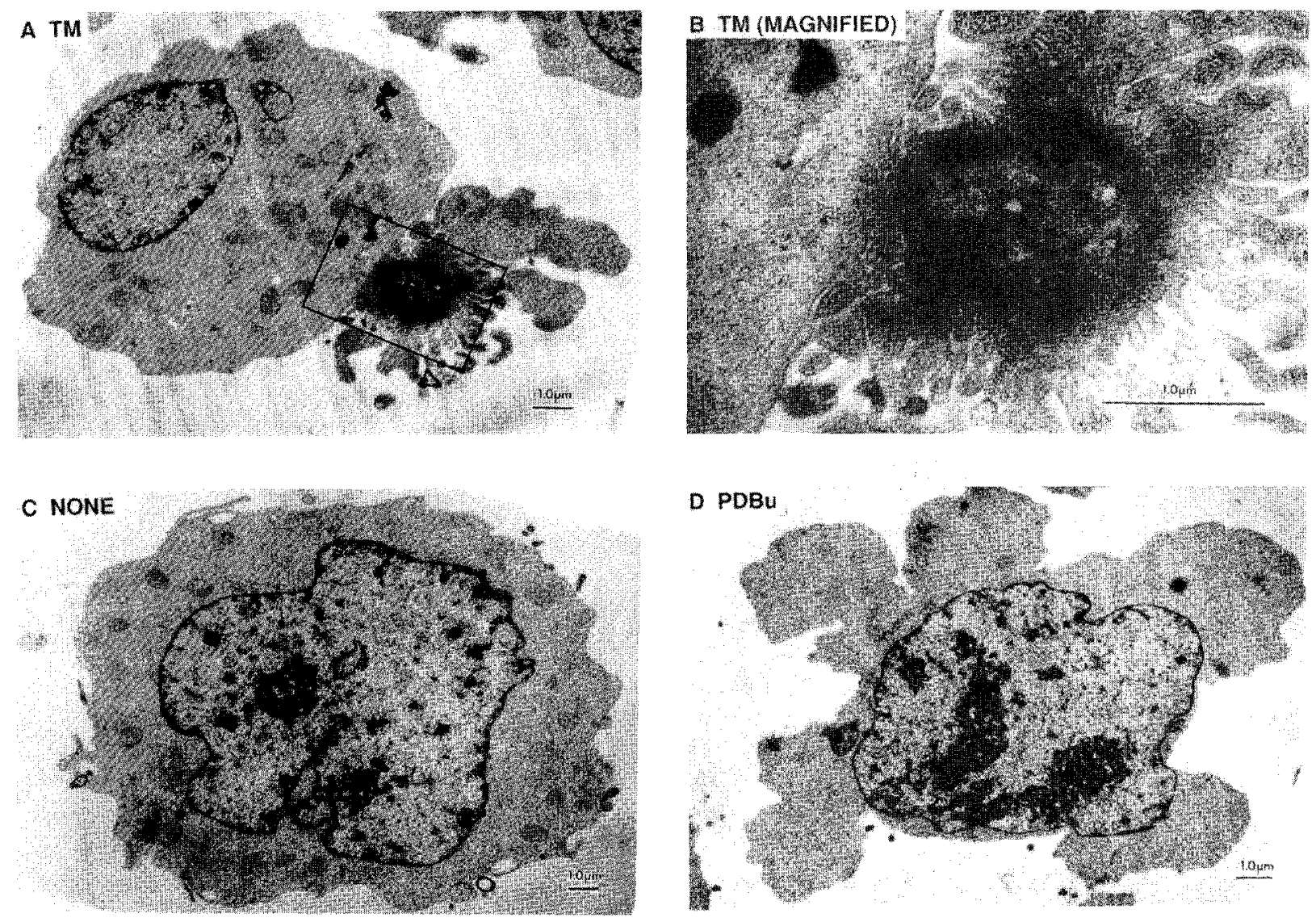

Fig. 5. TEM observation of tautomycin treated K562 cells.

K562 cells were treated with tautomycin $(30 \mu \mathrm{g} / \mathrm{ml} ; \mathrm{A}, \mathrm{B})$ or PDBu $(1 \mu \mathrm{g} / \mathrm{ml}$; D) for $15 \mathrm{~min}$. C, untreated cells. B, high magnification of A within the square.

Fernandez et al. (19) reported that microinjection of PP1 but not of type IIA phosphatase (PP2A) induces microfilament reorganization. Fifty percent inhibitory concentration $\left(\mathrm{IC}_{50}\right)$ of tautomycin and okadaic acid against PP1 are $32 \mathrm{nM}$ and $224 \mathrm{nM}$ whereas $50 \%$ effective dose $\left(\mathrm{ED}_{50}\right)$ of tautomycin and okadaic acid for the morphological changes are $4.0 \mu \mathrm{M}$ and $1.4 \mu \mathrm{M}$ (9). The comparatively high concentration required for the induction of morphological changes may be due to permeability of the compounds since overnight exposure to $0.4 \mu \mathrm{M}$ tautomycin induces blebs (6).

$\mathrm{PDBu}$, a potent activator of $\mathrm{PKC}$, induced surface blebs but not segmentation of cells and accumulation of F-actin, indicating that only the first step but not the second step may proceed through phosphorylation mediated by PKC. Actinfilaments bind to plasma membrane through various actin binding proteins (20) including vinculin and annexin which are phosphorylated by several kinases $(21,22)$. Phorbol esters reorganize actin and its binding proteins $(23,24)$. Blebbing was also observed in melanoma cells deficient in the actinfilament cross-linking protein, filamin (25). Therefore, it is possi- ble that tautomycin induces the detachment of F-actin from the plasma membrane through the phosphorylation of these actin binding proteins. Alternatively, phosphorylation of myosin light chain (MLC) may induce surface blebs since Fishkind et al. (26) reported that microinjection of MLC kinase induces blebs on the surface of NRK cells. However, the blebs were delineated by intense cortical actin, whereas F-actin was absent in the blebs induced by tautomycin.

Chartier et al. (27) reported that calyculin A induced rapid morphological changes of mouse fibroblasts and increased phosphorylation of vimentin and MLC as well as that of an unidentified $400 \mathrm{kDa}$-protein. They also observed a ball-like electron-dense structure in the cells which was connected to the nucleus through a filamentous structure. The accumulation center of F-actin we observed is similar in morphology to a ball-like structure although our structure is ring-like rather than balllike. Also, we could find no filamentous structures around the accumulation of actin filaments. Changes of filamentous structure may be more easily observed in fibroblasts than in myeloid cells. 
Acknowledgments. We thank Drs. H. Fujiki and N. Fusetani for kind gift of okadaic acid and calyculin A. We are grateful to Hitachi Co. Ltd., for help in SEM observation, Drs. D.H. Hartshorne, S. Watabe and M. Hori, for their critical discussion, and Dr. M. Schaechter for help in the preparation of the manuscript. This work was supported in part by a grant from the New Energy and Industrial Technology Development Organization and by a Grant-in-Aid for Cancer Research from the Ministry of Education, Science and Culture of Japan.

\section{REFERENCES}

1. CoHen, P. (1989). The structure and regulation of protein phosphatases. Annu. Rev. Biochem., 58: 453-508.

2. Cheng, X., Kihara, T., Kusakabe, H., Magae, J., Kobayashi, Y., FANG, R., Ni, Z., Shen, Y., Ko, K., Yamaguchi, I., and Isono, K. (1987). A new antibiotic, tautomycin. J. Antibiot., 40: $907-909$.

3. Cheng, X., Ubukata, M., and Isono, K. (1990). The structure of tautomycin, a dialkyl maleic anhydride antibiotic. J. Antibiot., 43: 809-819.

4. Ubukata, M., Cheng, X., and Isono, K. (1990). The structure of tautomycin. J. Chem. Soc. Chem. Commun., 3: 244246.

5. Osada, H., Magae, J., Watanabe, C., and Isono, K. (1988). Rapid screening method for inhibitors of protein kinase C. $J$. Antibiot., 41: 925-931.

6. Magae, J., Watanabe, C., Osada, H., Cheng, X., and Isono, K. (1988). Induction of morphological change of human myeloid leukemia and activation of protein kinase $\mathrm{C}$ by a novel antibiotic, tautomycin. J. Antibiot., 41: 932-937.

7. Suganuma, M., Fujiki, H., Suguri, H., Yoshizawa, S., Hirota, M., Nakayasu, M., OjiKa, M., Wakamatsu, K., YAmadA, K., and Sugrmura, T. (1988). Okadaic acid: an additional non-phorbol-12-tetradecanoate-13-acetate-type tumor promoter. Proc. Natl. Acad. Sci. USA, 85: 1768-1771.

8. Suganuma, M., Fujiki, H., Furuya-Suguri, H., Yoshizawa, S., Yamamoto, S., Kato, Y., Fusetani, N., and Sugimura, T. (1990). Calyculin A, an inhibitor of protein phosphatases, a potent tumor promoter on CD-1 mouse skin. Cancer Res., 50: $3521-3525$.

9. Magae, J., Osada, H., Fujiki, H., SaIdo, T.C., Suzuki, K., NAGAI, K., YamasaKi, M., and Isono, K. (1990). Morphological changes of human myeloid leukemia K562 cells by a protein phosphatase inhibitor, tautomycin. Proc. Jpn. Acad. Ser. B, 66: 209-212.

10. Sassa, T., Richter, W.W., Uda, N., Suganuma, M., Suguri, H., Yoshizawa, S., and Fujiki, H. (1989). Apparent "activation" of protein kinases by okadaic acid class tumor promoters. Biochem. Biophys. Res. Commun., 159: 939-944.

11. Hori, M., Magae, J., Han, Y., Hartshorne, D.J., and KARAKI, H. (1991). A novel protein phosphatase inhibitor, tautomycin. Effect on smooth muscle. FEBS Lett., 285: 145148.

12. MacKintosh, C. and Klumpr, S. (1990). Tautomycin from the bacterium Streptomyces verticillatus: Another potent and specific inhibitor of protein phosphatase 1 and 2A. FEBS Lett., 227: $137-140$.
13. Shinji, H., Kaiho, S., Nakano, T., and Yoshida, T. (1991). Reorganization of microfilaments in macrophages after LPS stimulation. Exp. Cell Res., 193: 127-133.

14. Castagna, M., Takai, Y., Tanaka, Y., Miyake, R., and NishizUKA, Y. (1982). Direct activation of calcium-activated, phospholipid dependent protein kinase by tumor-promoting phorbol esters. J. Biol. Chem., 257: 7847-7851.

15. Takai, A., Bialojan, C., Troschka, M., and Ruegg, J.C. (1987). Smooth muscle myosin phosphatase inhibition and force enhancement by black sponge toxin. FEBS Lett., 217: 8184.

16. Bialojan, C. and TAKai, A. (1988). Inhibitory effect of a marine-sponge toxin, okadaic acid, on protein phosphatases. Specificity and kinetics. Biochem. J., 256: 283-290.

17. Ishihara, H., Martin, B.L., Brautigan, D.L., Karaki, H., Ozaki, H., Kato, Y., Fusetani, N., Watabe, S., Hashimoto, K., Unmura, D., and Hartshorne, D.J. (1989). Calyculin-A and okadaic acid: Inhibition of protein phosphatase activity. Biochem. Biophys. Res. Commun., 159: 871-877.

18. Bilkstad, I., Markey, F., Carisson, L., Persson, T., and LINDBERG, U. (1978). Selective assay of monomeric and filamentous actin in cell extracts, using inhibition of deoxyribonuclease I. Cell, 15: 935-943.

19. Fernandez, A., Brautigan, D.L., Mumby, M., and Lamb, N.J.C. (1990). Protein phosphatase type-1, not type-2A, modulates actin microfilament integrity and myosin light chain phosphorylation in living nonmuscle cells. J. Cell Biol., 111: 103-112.

20. HaRtwig, J.H. and Kwiatkowski, D.J. (1991). Actin-binding proteins. Curr. Op. Cell Biol., 3: 87-97.

21. GERKE, V. (1989). Tyrosine protein kinase substrate p36: a member of the annexin family of $\mathrm{Ca}^{2+} /$ phospholipid-binding proteins. Cell Motil. Cytoskeleton, 14: 449-454.

22. Отто, J.J. (1990). Vinculin. Cell Motil. Cytoskeleton, 16: 16.

23. Schliwa, M., Nakamura, T., Porter, K.R., and Euteneuer, U. (1984). A tumor promoter induces rapid and coordinated reorganization of actin and vinculin in cultured cells. $J$. Cell Biol., 99: 1045-1059.

24. MeIGS, J.B. and WANG, Y. (1986). Reorganization of alpha-actinin and vinculin induced by a phorbol ester in living cells. $J$. Cell Biol., 102: 1430-1438.

25. BYers, M.C. (1981). Cell migration and actin organization in cultured human primary, recurrent cutaneous metastatic melanoma: time-lapse image analysis. Am. J. Pathol., 139: 423-435.

26. FISHKIND, D.J., CAO, L., and WANG, Y. (1991). Microinjection of the catalytic fragment of myosin light chain kinase into dividing cells: Effect on mitosis and cytokinesis. J. Cell Biol., 114: $967-975$.

27. Chartier, J., Rankin, L.L., Allen, R.E., Kato, Y., Fusetani, N., Watabe, S., and Hartshorne, D.J. (1991). Calyculin-A increases the level of protein phosphorylation and changes the shape of $3 \mathrm{~T} 3$ fibroblasts. Cell Motil. Cytoskeleton, 18: $26-40$.

(Received for publication, August 6, 1992 and in revised form, December 24, 1992) 